\title{
PERBANDINGAN REGISTRABILITAS MEREK SUARA DI UNI EROPA, AUSTRALIA DAN INDONESIA SERTA PROBLEMATIKANYA
}

\author{
Markus Yohanis Hage \\ Fakultas Hukum, Universitas Nusa Cendana \\ Jl. Adisucipto Penfui, Kupang, Nusa Tenggara Timur, 85361 \\ markushage323@gmail.com
}

\begin{abstract}
The purpose of this article is to discuss sound mark registrability in Indonesia by comparing it to the similar issue in the European Union and Australia. Compared to the European Union and Australia, which have more advanced sound mark rules, Indonesia still has some problems in the form of the absence of a sound mark definition and no special requirements related to the registrability of sound mark and the example notation, sound recording, sonogram and the duration, which creates legal uncertainty when a sound marks is going to be registered. It is recommended that the relevant Indonesian authroties should further succinctly define sound mark as well as determine clearly the requirements for sound mark registrability in Indonesia.
\end{abstract}

Keywords: Mark; Sound Mark; Notation; Sound Recording; Sonogram; Registrability.

\begin{abstract}
Abstrak
Tujuan artikel ini adalah membahas problematika merek suara di Indonesia dengan membandingkannya dengan isu yang sama di Uni Eropa dan Australia. Dibandingkan Uni Eropa dan Australia, yang pengaturan merek suaranya telah lebih maju, Indonesia masih menyisakan masalah berupa ketiadaan definisi merek suara dan ketiadaan syarat khusus terkait registralibitas merek suara berserta contohnya mengenai notasi, rekaman suara, sonogram dan termasuk durasinya sehingga menimbulkan ketidakpastian hukum ketika suatu merek suara didaftarkan. Disarankan agar pihak berwenang terkait di Indonesia perlu secara tepat mendefinisikan merek suara sekaligus menentukan secara jelas syarat registrabilitas merek suara di Indonesia.
\end{abstract}

Kata Kunci: Merek Suara; Notasi; Sonogram; Rekaman Suara; Registrabilitas.

\section{A. Pendahuluan}

Salah satu perkembangan positif dalam Undang-Undang No. 20 Tahun 2016 Tentang Merek dan Indikasi Geografis (UU Merek dan IG 2016) adalah dimasukannya non-traditional mark berupa merek suara sebagai salah satu tanda pembeda dalam merek. Hal ini terlihat dalam rumusan Pasal 1 angka 1 UU Merek dan IG 2016 yang menyatakan:

Merek adalah tanda yang dapat ditampilkan secara grafis berupa gambar, logo, nama, kata, huruf, angka, susunan warna, dalam bentuk 2 (dua) dimensi dan/atau 3 (tiga) dimensi, suara, hologram, atau kombinasi dari 2 (dua) atau lebih unsur tersebut untuk membedakan barang dan/atau jasa yang diproduksi oleh orang atau badan hukum dalam kegiatan perdagangan barang dan/atau jasa.

Konsekuensi dari dimasukkannya suara sebagai tanda pembeda dalam merek ialah suara merupakan salah satu lingkup perlindungan merek sebagaimana 
diamanatkan dalam Pasal 2 ayat (3) UU Merek dan IG 2016 yakni:

Merek yang dilindungi terdiri atas tanda berupa gambar, logo, nama, kata, huruf, angka, susunan warna, dalam bentuk 2 (dua) dimensi dan/atau 3 (tiga) dimensi, suara, hologram, atau kombinasi dari 2 (dua) atau lebih unsur tersebut untuk membedakan barang dan/atau jasa yang diproduksi oleh orang atau badan hukum dalam kegiatan perdagangan barang dan/atau jasa.

UU Merek dan IG 2016 dan Peraturan Menteri Hukum dan HAM No. 67 tahun 2016 tentang Pendaftaran Merek (Permenkumham Pendaftaran Merek 2016) hanya mengatur syarat terkait merek suara yang bersifat sangat umum seperti perlu melampirkan label merek suara berupa notasi, rekaman suara dan sonogram. Persoalan mengemuka ketika UU Merek dan IG 2016 dan Permenkumham Pendaftaran Merek 2016 tidak memberikan definisi tentang merek suara dan tidak juga memberikan contoh membuat notasi, rekaman suara dan sonogram termasuk durasinya. Syarat yang bersifat umum bagi pendaftaran merek suara, tanpa penjelasan yang disertai contoh ketika harus melampirkan label merek suara berupa notasi, rekaman suara dan sonogram dan durasinya tersebut telah menimbulkan ketidakpastian hukum bagi upaya pendaftaran merek suara. Ketiadaan definisi merek suara dan ketiadaan peraturan pelaksanaan khusus terkait tentang syarat pendaftaran merek suara atau registrabilitas merek suara yang rinci dan jelas di atas bisa menimbulkan multitafsir dan ketidakpastian hukum bagi perdaftaran merek suara. Oleh karenanya, artikel ini bertujuan untuk menawarkan sebuah terobosan hukum untuk mengatasi persoalan yang dihadapi terkait dengan definisi merek suara dan regsitrabilitas merek suara di Indonesia.

Artikel ini membahas satu tema sentral yakni perbandingan perkembangan registrabilitas merek suara di Uni Eropa dan Australia serta problematika registrabilitas merek suara di Indonesia. Untuk merumuskan syarat registrabilitas merek suara, perlu ditelusuri terlebih dahulu perkembangan merek suara dan regsitrabilitasnya dalam ketentuan internasional, undang-undang dan praktek di jurisdiksi lainnya seperti di Uni Eropa dan Australia. Uni Eropa sengaja dipilih untuk dibahas karena tanda berupa suara telah menjadi bagian dari definisi merek dan merek suara telah didefinisikan secara jelas melalui putusan Pengadilan. Sedangkan Australia dipilih karena UU Mereknya telah mengatur tanda suara sebagai bagian dari merek, registrabilitas merek suara telah diatur dalam peraturan pelaksanannya dengan lebih konkrit dan praktek pendaftaran merek suara telah berkembang dengan baik. Dengan perbadingan registrabilitas merek suara di Australia dan Uni Eropa diharapkan dapat memberi masukan bagi penyusunan registrabilitas merek suara di Indonesia.

Selanjutnya, sekalipun registrabilitas merek suara masih sangat umum dan belum jelas pengaturannya di Indonesia, isu ini akan tetap dibahas mengingat dalam prakteknya, walau belum banyak, telah terdapat sejumlah pendaftaran merek suara yang diterima dan ditolak. Tentu registrabilitas merek suara di Indonesia akan dilihat dari syarat pendaftaran merek pada umumnya yang diterapkan juga bagi pendaftaran merek suara dan persoalan yang ditimbulkannya.

Pembahasan atas tema sentral registrabilitas merek suara di Uni Eropa dan Australia di atas akan diawali dengan melihat perkembangan pengaturan merek suara sebagai non-traditional marks sehingga memberikan pemahaman yang cukup untuk memahami konsep nontraditional marks. Diharapkan, pembahasan mengenai problematika registrabilitas merek suara di Indonesia yang dibandingkan dengan perkembangan pengaturan registrabilitas merek suara di Uni Eropa dan Australia dapat memberikan perspektif bagi Indonesia cq. Pemerintah dan DPR untuk merevisi UU Merek dan IG 2016 dan/atau memberikan sumbangan pikiran bagi 
perumusan definisi merek suara dan registrabilitas merek suara oleh Kementerian Hukum dan HAM RI.

\section{B. Pembahasan}

\section{Perkembangan Merek Suara sebagai Bagian dari Non-traditional Marks}

Merek suara sebenarnya telah diperkenalkan secara tidak langsung dalam Trade Related Aspects of Intellectual Property Rights (TRIPS) 1995. Menurut Artikel 15.1 TRIPS setiap tanda ataupun kombinasi dari tanda-tanda dapat didaftarkan sebagai sebuah merek dagang sekalipun sebuah syarat bahwa merek tersebut 'secara visual dapat dilihat' ("visually perceptible") dapat diterapkan. Frasa visually perceptible kemudian diterjemahkan oleh berbagai negara nasional, termasuk Indonesia dalam hukum mereknya dengan menggunakan istilah penampilan grafis (graphical representation) (Vide Pasal 1 angka 1 UU Merek dan IG 2016, Article 9(1) the Bulgarian Trade Mark Law 2010, Section 3 the German Trademark Act 2019, Section 5 the New Zealand Trade Marks Act 2002).

Tanda suara sebagai bagian dari nontraditional marks mulai mendapat perhatian serius International tahun 2006 ketika terjadi perubahan atas Law Trade Mark Treaty 1984 dan digantikan dengan Singapore Treaty on the Law of Trademarks 2006 (Singapore Trademarks Treaty 2006). Dalam peraturan pelaksanaannya yakni Rule 4 Peraturan di bawah Singapore Trademarks Treaty tahun 2011 ditetapkan sejumlah nontraditional marks yakni merek yang dapat dilihat (visible marks) dan dapat didaftarkan seperti hologram, merek tiga dimensi, merek berwarna, merek posisi dan merek bergerak dan merek yang tidak terlihat (non-visible marks) seperti suara, penciuman, dan rasa. World Intellectual Property Organization menyatakan Singapore Trademarks Treaty 2006 merupakan instrumen hukum internasional pertama yang secara tegas mengakui eksistensi non-traditional marks di atas.
Rule 3 (9) Peraturan di bawah Singapore Trademarks Treaty tahun 2011 secara tidak langsung mendefinisikan merek suara ketika mengatur pendaftaran merek suara dengan menyatakan bahwa [Merek Suara] Jika permohonan berisi pernyataan yang menyatakan bahwa merek tersebut adalah merek suara, representasi merek tersebut seharusnya, ...., terdiri dari notasi musik pada tangga nada, atau deskripsi dari suara yang menentukan merek, atau rekaman analog atau digital dari suara tersebut, atau kombinasinya'. Jadi, dari syarat pendaftaran di atas terlihat bahwa merek suara merupakan notasi musik yang dituangkan dalam tangga nada atau deskripsi (gambaran) dari suara yang menentukan merek, atau rekaman analog atau digital dari suara tersebut, atau kombinasinya.

Dengan demikian Non-traditional marks terdiri atas dua yakni visible marks berupa warna, bentuk, hologram dan gambar bergerak dan non-visible marks seperti suara, penciuman/aroma dan cita rasa Jadi non-conventional marks itu meliputi kelima panca indra manusia yakni telinga (pendengaran), hidung (penciuman), kulit (rasa), mata (penglihatan), dan lidah (pengecapan) (Bretonniere \& Rodari, 2009; Calboli, 2018; Calboli \& Senftleben, 2018; Carapeto, 2016; Lukose, 2015)

Sejak berlaku efektifnya Singapore Trademarks Treaty 2006 di tahun 2009 yang diikuti dengan pengaturan lebih lanjut mengenai pelaksanaan pendaftaran merek suara di bawah Singapore Trademarks Treaty tahun 2011, sejumlah negara, termasuk Indonesia, lalu merevisi UU Merek dan IG-nya dimana tanda berupa suara yang sebelumnya tidak merupakan tanda dalam merek, lalu dijadikan bagian dari tanda dan definisi merek (Gheewala, 2007; Seville, 2009; Vaver, 2005).

Sedangkan terkait definisi merek suara (World Intellectual Property Organization (WIPO), 2008) mendefinisikan merek suara sebagai tanda yang dapat terdiri dari 'suara musik, baik yang sudah ada sebelumnya atau yang dipesan khusus untuk tujuan pendaftaran merek dagang. Suara-suara ini 
mungkin juga terdiri dari suara non-musik, baik yang ada di alam (misalnya suara binatang atau suara yang dihasilkan oleh fitur meteorologi atau geografis) atau diproduksi oleh mesin dan perangkat buatan manusia lainnya'. Selanjutnya pengakuan atas registrabilitas merek suara dipertegas oleh Madrid Protocol (diperbaharui 2018) dalam A.I. Section 9(b) 07.42 yang intinya menyatakan bahwa ketika merek yang didaftarkan itu merek tiga dimensi seperti merek suara maka harus menyertakan pula representasi grafisnya atau notasi musik konvensional atau deskripsi dalam kata atas merek suara (World Intellectual Property Organization (WIPO), 2018).

Definisi yang agak mirip dikemukakan oleh Asosiasi Merek dagang Internasional yang mentakrifkan (mengonseptualisasikan) merek suara sebagai tanda yang dapat berupa 'sebuah jingle atau musik atau suara lainnya. Suara ini bisa juga berupa kutipan singkat dari sebuah komposisi atau keseluruhan karya musik. Dalam beberapa kasus, suara ini mungkin merupakan reproduksi suara sehari-hari, mungkin dalam keadaan yang tidak biasa'.

Sementara itu, The World Intellectual Property Organization (World Intellectual Property Organization (WIPO), 2009) Standing Committee on the Law of Trademarks, Industrial Designs and Geographical Indications (SCT) menyatakan bahwa kantor kekayaan intelektual dari berbagai negara dapat mensyaratkan bahwa 'representasi merek suara terdiri dari notasi musik pada tangga nada, deskripsi suara yang membentuk tanda, atau rekaman analog atau digital dari suara itu - atau kombinasi apa pun darinya. Jika pengarsipan elektronik tersedia, file elektronik dapat dilampirkan dalam permohonan pendaftaran. Namun, untuk beberapa wilayah hukum, notasi musik pada tangga nada saja sudah dianggap cukup mewakili merek'.

Dengan demikian merek suara itu dapat merupakan tanda dalam merek baik berupa suara alamiah atau buatan manusia dimana suara tersebut dapat dibuat dalam bentuk atau direpresentasikan secara grafis berupa notasi, rekaman suara, dan sonogram, yang dipakai dalam kegiatan barang dan jasa dan dimaksudkan untuk membedakan barang dan jasa sejenis yang diproduksi oleh pihak lainnya.

\section{Syarat Pendaftaran Merek Suara atau Registrabilitas Merek Suara di Uni Eropa}

Merek suara di Uni Eropa pada awalnya tidak dimasukan dalam definisi merek suara. Hal ini tercermin dalam Article 2 dari the EU Trademark Directive 89/104 yang merumuskan bahwa tanda dalam merek dapat terdiri dari 'tanda apapun yang dapat diwakili secara grafis, terutama kata-kata, termasuk nama pribadi, desain, huruf, angka, bentuk barang atau kemasannya, asalkan tanda tersebut mampu membedakan barang atau jasa suatu usaha dari yang lain'.

Dalam perkembangannya di Uni Eropa, ketika memberikan arahan bagi negaranegara anggotanya untuk menyusun hukum merek pada level nasional melalui Trademark Directive (EU) 2015/2436, Dewan Uni Eropa kemudian memasukan merek suara dalam definisi merek sebagaimana terlihat dalam Article 3 sebagai berikut:

A trade mark may consist of any signs, in particular words, including personal names, or designs, letters, numerals, colours, the shape of goods or of the packaging of goods, or sounds, provided that such signs are capable of:

(a) distinguishing the goods or services of one undertaking from those of other undertakings; and

(b) being represented on the register in a manner which enables the competent authorities and the public to determine the clear and precise subject matter of the protection afforded to its proprietor (European Union, 2015)

Dari definisi di atas, diketahui bahwa apapun mereknya, termasuk merek suara, merek tersebut harus membedakan barang 
dan jasa satu dengan lainnya dan ketika didaftarkan, merek tersebut dipresentasikan secara jelas dan tepat sehingga memampukan otoritas berwenang dan publik untuk mengidentifikasinya. Namun Directive (EU) 2015/2436 tidak memberikan definisi mengenai merek suara. Perlu dicatat bahwa sesunguhnya pengaturan mengenai merek suara dalam Directive (EU) 2015/2436 di atas merupakan penyesuaian pengaturan di level Uni Eropa yang didasarkan pada putusan Pengadilan Eropa (European Justice of Court) dimana dalam putusan Pengadilan Eropa-lah tanda suara dimasukan sebagai bagian dari definisi merek sekaligus memberikan definisi yang lebih jelas mengenai merek suara.

Dengan kata lain definisi merek suara di Uni Eropa lahir dari putusan Pengadilan Eropa yang bermula dari gugatan atau sengketa merek suara di Belanda dalam kasus Shield Mark BV v. Joost Kist (Case C-283/01). Dalam perkara ini, pihak Penggugat yakni Shield Mark menggugat Joost Kist karena dituduh telah menggunakan merek suaranya. Dalam positanya, Penggugat mendalilkan bahwa dia memiliki merek suara yang terdiri dari penggalan musik yang diciptakan Komposer Beethoveen yang berjudul Für Elise dan telah digunakan dalam sebagai iklan di radio, perangkat lunak dan surat kabar. Penggugat menuduh Tergugat telah melanggar merek suara Penggugat karena telah menggunakan merek suaranya tanpa ijin dalam iklan Tergugat (Shield Mark BV v. Joost Kist (Case C-283/01)).

Pengadilan Hoge Raad Belanda yang memeriksa perkara ini memutuskan untuk menolak gugatan ini. Penggugatnya lalu membawa kasus ini ke Pengadilan Eropa (European Justice of Court). Ketika mengadili perkara di atas, Pengadilan Eropa memutuskan juga menolak gugatan Penggugat karena merek suara yang diklaim Penggugat dimata Pengadila Eropa tidak jelas dan tidak tepat karena hanya menuliskan Sembilan nada pertama dari tangga nada Für Elise dan hanya mempresentasikannya dengan nada music E,
D\#, E, D\#, E, B, D, C, A. Tetapi yang menarik ialah Pengadilan Eropa dalam putusannya mendasarkan pada Article 2 of EU Trademark Directive 89/104 yang belum mamasukkan suara sebagai bagian dari tanda dalam merek yang dilindungi.

Pengadilan Eropa dalam pertimbangannya (Court of Justice EU, 2003, para. 41) menyatakan bahwa "Pasal 2 Directive harus diartikan bahwa tanda suara harus dapat dianggap sebagai merek dagang asalkan mampu membedakan barang atau jasa suatu usaha dari usaha lain dan dapat ditampilkan secara grafis".

Selanjutnya Pengadilan Eropa (Court of Justice EU, 2003, para. 64) juga menyatakan bahwa 'Pasal 2 Directive harus diartikan bahwa suatu merek dapat terdiri dari tanda yang tidak dengan sendirinya dapat dilihat secara visual, asalkan dapat direpresentasikan secara grafis, terutama melalui gambar, garis atau karakter, dan representasi yang jelas, tepat, mandiri, mudah diakses, dipahami, memiliki durasi, dan objektif ', ...dan 'umumnya, kondisi seperti itu dipenuhi oleh representasi pada tangga nada musik'.

Dari pertimbangan Putusan Pengadilan Eropa di atas nampak bahwa sebuah merek suara tidak hanya harus memiliki ciri khas (pembeda) sebagai merek dagang yang membedakan barang/jasa jenis yang diproduksi pihak lainya, tetapi juga harus dapat ditampilkan secara grafis dengan cara yang jelas, tepat, lengkap, mudah diakses, dapat dipahami, punya waktu tertentu, dan obyektif, dan umumnya, pemenuhan atas syarat-syarat tersebut dilakukan dalam sebuah representasi 'musical stave' (tangga nada) atau graphical representation (tampilan grafis).

Menarik untuk dicermati bahwa dalam Putusan di atas, Pengadilan Eropa sekalipun telah memberikan kepastian mengenai registrabilitas merek suara di Uni Eropa tetapi pada saat yang sama menciptakan kebingungan karena Pengadilan lalu menghilangkan alternatif deksripsi tertulis dalam pendaftaran merek suara yakni tanda berupa nada-nada yang membuat musik, 
tangisan binatang, penciptaan huruf atau rangkaian kata yang menduplikasi suara yang terdengar atau onomatopoeia atau tahapan sederhana dari notasi musik (Court of Justice EU, 2003, paras. 60, 61, 62).

Hukum yang lahir dari Putusan Pengadilan (case law) di atas, yang mewajibkan syarat graphical representation nyatanya telah melahirkan interpertasi yang berbeda-beda. Akibatnya sejumlah merek seperti merek berwarna dan merek tiga dimensi lebih banyak diterima pendaftarannya, sementara merek suara dan merek penciuman mengalami kesulitan. Situasi ini telah menimbulkan ketidakpastian hukum dalam proses pendaftaran karena umumnya Pengadilan telah berulang kali menyatakan bahwa semua merek harus diperlakukan sama, dikomunikasikan dan diterima secara (Sandri \& Rizzo, 2003).

Dalam perkembangannya, sejak 1 Oktober 2017, Uni Eropa lalu merevisi hukum merek dagang-nya terutama terkait persyaratan graphical representation dalam pendafataran merek suara karena dianggap telah menyulitkan pendaftaran merek suara dan karena pada dasarnya merek suara itu tidak terlihat sehingga tidak diperlukan graphical representation. Penghapusan syarat graphical representation kemudian memungkinkan pendaftaran suara dengan menggunakan bentuk yang tepat dengan menggunakan teknologi yang umumnya tersedia sepanjang representasinya jelas, tepat, mudah diakses, dapat dimengerti, memiliki jangka waktu tertentu, dan obyektif (Kudrina, 2018).

Dengan demikian menjadi jelas bahwa di Uni Eropa tanda berupa suara dapat didaftarkan sebagai merek untuk membedakan barang dan jasa sejenis yang diproduksi pihak lainnya. Definisi merek suara dan registrabilitas merek suara di Uni Eropa lahir dari putusan Pengadilan Uni Eropa dimana untuk kepentingan pendaftaran, merek suara harus ditampilkan dengan cara yang jelas, tepat, lengkap, mudah diakses, dapat dipahami, punya waktu tertentu, dan obyektif, dan umumnya, pemenuhan atas syarat-syarat tersebut dilakukan dalam sebuah representasi tangga nada.

\section{Syarat Pendaftaran Merek Suara atau Registrabilitas Merek Suara di Australia}

Perkembangan pengaturan merek suara di Australia termasuk yang paling maju di dunia dan telah lebih dahulu berkembang jauh sebelum Uni Eropa menyesuaikan hukum merek dan merek suaranya (Clarke \& Kapnoullas, 2001; Scardamaglia \& Adams, 2016). Perubahan nyata terjadi tahun 1995 ketika terjadi perubahan UU Merek Australia (The Trade Marks Act 1995). Section 17 dari the Trade Marks Act 1995 mendefinisikan merek sebagai "Tanda yang digunakan, atau dimaksudkan untuk digunakan, untuk membedakan barang atau jasa yang berhubungan dengan atau disediakan dalam proses perdagangan oleh seseorang dari barang atau jasa yang berhubungan dengan atau disediakan oleh orang lain".

Sedangkan tanda (sign) itu sendiri menurut Section 6 dari the Trade Marks Act 1995 adalah 'Tanda yang dapat meliputi atau kombinasi dari huruf, kata, nama, tanda tangan, angka, perangkat, merek, judul, label, tiket, aspek kemasan, bentuk, warna, suara, atau aroma'. Jadi, sejak tahun 1995, jelas bahwa suara merupakan tanda yang diakui sebagai bagian dari merek yang bisa didaftarkan.

Tahun 1999 Kantor Kekayaan Intelektual Australia melalui Kantor Merek Dagang mengeluarkan pedoman berupa Manual of Practice and Procedure (Manual Praktek dan Prosedur) bagi pendaftaran merek. Dalam pedoman ini, definisi merek suara dan registrabilitas merek suara diatur. Dalam Part 21.6 dari Manual Praktek dan Prosedur, merek suara didefinisikan sebagai berikut:

Sebuah merek dagang suara dapat berupa suara pendengaran apapun. Suara itu dapat berupa bunyi riuh orkestra yang rumit, atau bunyi klik mekanis yang sederhana. Suara itu dapat dinyanyikan atau ucapan kata- 
kata, atau kombinasi suara dan bunyi lainnya. Suara itu dapat berupa suara gonggongan anjing, dering bel atau bayi menangis. Apapun suaranya, suara itu harus berfungsi dengan tujuan untuk mengidentifikasi sumber dari barang/jasa yang diperdagangkan sehubungan dengan penggunaan suara tersebut.

Part 6.1 Pedoman manual Kantor Dagang Australia juga mengatur mengenai representasi dan deskripsi merek dagang suara yang harus dipenuhi pemohon ketika mendaftarkan merek suaranya. Representasi dan deskripsi merek dagang suara harus memenuhi enam (6) kriteria. Pertama, permohonan atas suara sebagai merek dagang harus menyertakan representasi grafis dari merek tersebut. Kedua, notasi musik dapat diterima sebagai representasi grafis dari tanda suara yang terdiri dari karya musik. Namun, notasi musik yang panjang seperti notasi musik orkestra atau piano yang lengkap tidak mungkin memenuhi persyaratan pendaftaran. Ketiga, nama karya musik tertentu tidak dapat diterima sebagai representasi grafis kecuali jika informasi tambahan diberikan untuk mengidentifikasi rendisi tertentu yang diklaim sebagai merek dagang. Keempat, sebagaimana representasi grafis, pemohon harus memberikan deskripsi merek dagang yang jelas dan ringkas yang akan dimasukkan untuk mendukung permohonan tersebut. Kelima, pemohon harus menyediakan rekaman merek dagang pada media yang memungkinkan pemutaran ulang dengan mudah. Saat ini, media yang paling umum adalah CD, DVD dan rekaman MP3. Dan keenam, deskripsi dan rekaman representasi merek dagang tersebut harus secara bersama-sama mendefinisikan dengan jelas semua detail yang membentuk merek dagang tersebut.

Part 6.1 Pedoman manual Kantor Dagang Australia juga memberikan contoh dukungan deskripsi yang menyertai representasi. Pertama, Merek dagang berupa tanda suara. Merek ini terdiri dari suara anjing menggonggong seperti lagu tradisional "Greensleeves" sebagaimana diberikan dalam rekaman audio yang menyertai permohonan ini. Kedua, merek dagang yang terdiri dari suara dua langkah yang dilakukan oleh sapi di trotoar, diikuti dengan suara sapi melenguh (klip, klop, MOO) seperti yang tertera dalam rekaman yang menyertai aplikasi ini. Ketiga, merek dagang berupa suara sopran yang bernyanyi tanpa kata sesuai dengan nada yang diwakili dalam not musik yang dilampirkan pada permohonan. Merek dagang ini harus ditunjukkan dalam rekaman yang menyertai formulir permohonan ini. Dan kelima, merek dagang yang terdiri dari suara ketukan cepat berulang yang dibuat oleh tongkat kayu yang mengetuk tutup tong sampah logam yang secara bertahap menjadi lebih keras selama kurang lebih 10 detik. Suara didemonstrasikan dalam rekaman yang menyertai permohonan pendaftaran merek suara.

Selanjutnya Part 6.2 Pedoman manual Kantor Dagang Australia mengatur mengenai registrabilitas suara sebagai merek dagang sebagai berikut:

Merek suara dirancang untuk mengidentifikasi sumber perdagangan barang dan/atau wjasa melalui alat pendengaran ketimbang cara visual. Teknologi yang berkembang selama abad terakhir semakin mengekspos masyarakat pembeli ke iklan melalui suara, dan dengan demikian kemungkinan barang atau jasa dapat diidentifikasi dengan suara, bukan dengan presentasi visual.

Part 6.2 Pedoman Manual Kantor Dagang Australia mengatur lebih lanjut bahwa untuk dapat didaftarkan, pendaftaran harus memenuhi syarat merek suara atau registrabilitas merek suara dimana pertimbangan pertama yang perlu diperhatikan pemeriksa merek ialah apakah pendaftaran atas merek suara yang diklaim sebagai merek dagang tersebut dapat dipakai untuk membedakan jenis barang/jasa pemohon dengan dengan jenis barang/jasa sejenis yang telah ada. Untuk itu, seorang penguji merek perlu mempertimbangkan 
apakah suara tersebut memiliki aspek fungtional (functional aspects) atau apakah suara tersebut merupakan sesuatu yang umum dalam dunia perdagangan atau masyarakat luas.

Parts 6.2 juga menggariskan empat (4) jenis suara yang dapat dikategorikan sebagai memenuhi syarat mampu membedakan (tanda pembeda). Pertama, suara fungsional ("Functional" sounds) yakni 'suara yang, misalnya, disebabkan oleh pengoperasian normal suatu peralatan. Bunyi mesin sepeda motor adalah contoh bunyi yang berfungsi sehubungan dengan sepeda motor atau motor, dan oleh karena itu bunyi itulah yang mungkin ingin digunakan oleh pedagang lain untuk barang mereka sendiri...Tetapi suara fungsional yang umum seperti suara sirene dari mobil ambulans, pemadam kebakaran dan polisi tidak dapat didaftarkan sebagai merek suara...' (Part 6.2.1)

Kedua, suara yang memiliki kemampuan untuk membedakan (sounds which are capable of distinguishing). Suara yang tidak fungsional atau umum dalam perdagangan tidak dapat didaftarkan. Atau suara yang didaftarkan adalah suara harus memiliki kemampuan untuk membedakan dari barang/jasa sejenis (Part 6.2.2).

Ketiga, suara yang memiliki adaptasi yang tidak cukup untuk membedakan (sounds which have insufficient adaptation to distinguish). Jenis suara ini dapat berupa suara pada umumnya yang ingin digunakan oleh pedagang untuk barang atau jasanya. Suara yang telah dikenal umumnya bisa didaftarkan namun harus disertakan bukti dukungan yang banyak. Semakin sebuah suara adalah suara yang umum, semakin dibutuhkan banyak bukti untuk mendukung pendaftaran tersebut (Part 6.2.3).

Keempat, suara yang tidak memiliki adaptasi inheren untuk membedakan (sounds which have no inherent adaptation to distinguish). Suara yang fungsional atau sangat umum sangat munkin diinginkan oleh pedagang untuk didaftarkan. Dalam situasi seperti ini, suara sejenis ini tidak memiliki adaptasi inheren untuk membedakan. Oleh karenanya, pemeriksa merek harus memastikan pada saat tanggal pendaftaran, suara seperti ini harus mampu membedakan barang/jasa yang didaftarkan dengan barang/jasa sejenis (Part 6.2.4).

Dari uraian di atas terlihat bahwa definisi merek (marks), definisi tanda (signs), definisi merek suara dan registrabilitas merek suara atau syarat pendaftaran merek suara telah diatur detail dan jelas di Australia sehingga tidak menimbulkan multitafsir dan menjamin kepastaian hukum bagi pemohon merek suara di Australia.

\section{Syarat Pendaftaran Merek Suara atau Registrabilitas Merek Suara di Indonesia}

Sebagaimana telah dijelaskan di atas, merek suara tidak didefinisikan dalam UU Merek dan IG 2016. Tetapi beradasarkan Pasal 1 angka 1 UU Merek dan IG 2016 dapat dipastikan bahwa suara bisa didaftarkan dengan menampilkannya secara grafis (graphical representation). Mengingat tidak ada peraturan pelaksanaan khusus mengenai pendaftaran merek suara, maka pendaftaran merek suara harus mengikuti syarat pendaftaran merek pada umumnya.

Pendaftaran merek pada umumnya, baik pendaftaran merek yang menggunakan hak prioritas atau pendaftaran merek biasa atau yang tidak mengunakan hak prioritas (Rissy, 2020) diatur dalam Pasal 4 ayat (1 s.d 8) UU Merek dan IG 2016 Jo Pasal 3 ayat $(1,2,3)$ Peraturan Menteri Hukum dan HAM No. 67 Tahun 2016 Tentang Pendaftaran Merek. Khusus untuk pendaftaran merek suara, terdapat empat syarat (tentu harus memenuhi syarat administratif lainnya) yang harus dicermati secara seksama dan dipenuhi pemohon pendaftaran merek suara. Ke-empat syarat ini adalah a) permohonan merek (suara) harus melampirkan label merek (suara) (Pasal 4 ayat (4) UU Merek dan IG 2016 jo Pasal 3 ayat (3) huruf b Peraturan Menteri Hukum dan HAM No. 67 Tahun 2016), b) label merek suara yang dilampirkan adalah berupa notasi dan rekaman suara (Pasal 4 ayat (8) UU Merek dan IG jo Pasal 3 ayat (5) Peraturan Menteri 
Hukum dan HAM No. 67 Tahun 2016), dan c) jika label merek tidak dapat ditampilkan dalam bentuk notasi, maka label merek tersebut ditampilkan secara sonogram; dan d) tanda merek suara tersebut perlu dipresentasikan dalam bentuk grafis (Pasal 1 angka 1 UU Merek dan IG 2016).

Persoalannya ialah baik UU Merek dan IG 2016 maupun Peraturan Menteri Hukum dan HAM No. 67 Tahun 2016 tidak memberi penjelasan lebih lanjut mengenai arti rekaman rekaman suara, notasi dan sonogram, tidak menyertakan contoh notasi, contoh rekaman suara dan contoh sonogram, tidak juga memberikan definisi tentang merek suara. Kedua sumber hukum di atas juga tidak mengatur mengenai berapa panjang notasi tersebut (misalnya 10-12 notasi, berapa lama rekaman suara tersebut (misalnya 10-12 detik) dan berapa lama sonogram tersebut (misalnya 10-12 detik).

Akibatnya pemohon pendaftaran merek suara lalu mereka-reka cara pemenuhan syarat notasi, rekaman suara dan sonogram termasuk durasinya. Tentu kondisi seperti ini menimbulkan ketidakpastian hukum bagi pemohon pendaftaran merek suara dalam pemenuhan syarat-syarat tersebut yang berakibat pada penolakan permohonan pendaftaran merek suara. Persoalan ini dapat dilihat pada pendaftaran merek suara yang ditolak oleh Kemenkumham cq Dirjen Kekayaan Intelektual RI berdasarkan tanggapan yakni kasus D002006027137 yakni pendaftaran merek suara $\mathrm{MOO}=$ suara lenguhan sapi (Dirjen Kekayaan Intelektual, 2006) dan kasus D002017018614 yakni pendaftaran merek suara COMBIPHAR (Direktorat Jenderal Kekayaan Intelektual, 2017). Dalam kedua kasus ini, tidak ditulis secara tegas apa alasan penolakannya. Namun jika dicermati berkas penolakan permohonan pendaftaran yang didaftarkan, nampak bahwa permohonan merek suara Combiphar tersebut tidak menyertakan rekaman suara dari Combiphar tapi menyertakan not baloknya tanpa keterangan kata-kata COMBIPHAR yang diletakan di bawah not balok tersebut (Direktorat Jenderal Kekayaan Intelektual, 2017).
Selanjutnya jika dicermati berkas permohonan penolakan pendaftaran merek suara $\mathrm{MOO}=$ lenguhan suara sapi tidak terlihat baik label merek suara berupa not baloknya maupun rekaman suaranya tetapi hanya menyertakan label merek berupa ranagakain huruf MOO yang berwarna (Direktorat Jenderal Kekayaan Intelektual, 2006).

Dengan demikian, sekali lagi, dari dua kasus pendaftaran merek suara di atas dan jika dibandingkan dengan dua permohonan merek suara yang diterima (akan dibahas di bawah) terlihat jelas bahwa kedua pemohon pendaftaran merek suara tidak dapat memastikan keterpenuhan syarat pendaftaran merek suara yakni harus menyertakan notasi dan memberikan keterangan kata di bawah notasi merek suara yang dimohonkan. Ketidakpastian ini timbul karena memang tidak ada ketentuan khusus syarat pendaftaran merek suara sebagaimana yang berlaku di Uni Eropa dan Australia.

Sebagai pembanding, dibahas juga dua kasus pendaftaran merek suara yang diterima pendaftarannya. Pertama, kasus IDM000754741 yakni pendaftaran merek suara HISAMITSU (Direktorat Jenderal Kekayaan Intelektual, 2020b). Jika dicermati berkas permohonannya disertai not balok dan keterangan kata HISAMITSU yang diletakan di bawah not baloknya (Direktorat Jenderal Kekayaan Intelektual, 2020b).

Kedua, kasus IDM000754741 yakni pendaftaran merek suara MAMYPOKO PANTS TETAP KERING yang juga diterima pendaftarannya. Jika dicermati berkas permohonannya juga disertai not balok dan keterangan kata HISAMITSU yang diletakkan di bawah not baloknya (Direktorat Jenderal Kekayaan Intelektual, 2020a).

Dengan demikian, sekali lagi, dalam kedua kasus permohonan pendaftaran merek suara yang diterima di atas terlihat pola yang sama yakni pendaftaran tersebut disertai dengan not balok dan di bawah not balok. Nampaknya pola dan syarat pendaftaran seperti ini yang berlaku saat ini di Indonesia terkait dengan pendaftaran merek suara. 
Sekalipun demikian, persyaratan yang dipakai dalam praktek saat ini seperti yang diungkapkan di atas tetap tidak memberikan kepastian hukum bagi pemohon pendaftaran merek suara di Indonesia. Untuk itu, merek suara perlu didefinisikan terlebih dahulu. Dalam konteks ini, Penulis mendefinisikan merek suara sebagai sebuah tanda suara yang ditampilkan secara grafis berupa suara alam maupun suara non-alam atau buatan manusia baik berupa kata-kata atau kombinasi suara atau bebunyian lainnya yang dipakai dalam kegiatan produksi barang dan jasa dengan tujuan membedakan barang dan jasa sejenis yang diproduksi oleh orang atau badan hukum lainya.

Selanjutnya registralibtas merek suara perlu diatur secara lebih tegas, limitatif dan rinci baik melalui perubahan UU Merek dan IG 2016 ataupun melalui Peraturan Menteri Hukum dan HAM. Dalam konteks ini, Penulis menyampaikan saran konkrit registrabilitas merek suara di Indonesia yakni bahwa merek suara dapat didaftarkan jika: a) tanda suara tersebut harus dipakai dalam kegiatan perdagangan barang dan jasa; b) tanda suara tersebut harus membedakan barang dan jasa sejenis yang diproduksi oleh orang atau badan hukum lainnya; c) label merek suara harus ditampilkan secara grafis berupa notasi, rekaman suara dan/atau sonogram; d) dalam hal tampilan grafis berupa notasi, maka jumlah notasi maksimal adalah 12; e) dalam hal tampilan grafis berupa rekaman suara maka durasi maksimalnya adalah 12 detik; f) dalam hal tampilan grafis berupa notasi, maka perlu disertai dengan keterangan katakata yang diletakan di bawah notasi yang disertakan dalam permohonan; g) dalam hal tampilan grafis berupa sonogram maka perlu disertakan notasinya dengan jumlah maksimal adalah 12 dan durasi maksimal 12 detik.

\section{Simpulan}

Merek suara telah merupakan bagian dari non-conventional marks yang dapat didaftarkan di Uni Eropa, Australia dan Indonesia. Namun, tidak sebagaimana di
Uni Eropa dan Australia dimana registrabilitas merek suara telah diatur secara jelas, limitatif dan rinci, registabilitas merek suara masih menyisakan masalah ketidakpastian hukum karena merek suara tidak didefinisikan dalam UU Merek dan IG 2016 dan Permenkumham No. 67 tahun 2016 tentang Pendaftaran merek.

Registrabilitas merek suara yang tidak diatur khusus dan registrabilitas (syarat pendaftaran) merek suara yang berlaku sama dengan pendaftaran merek pada umumnya dalam prakteknya telah menimbulkan ketidakpastian hukum bagi pemohon pendaftaran merek suara untuk memperoleh perlindungan merek suara yang diinginkan. Untuk mengatasi ini persoalan ini, terdapat dua saran yang perlu dipertimbangkan yakni melakukan perubahan atas UU Merek dan IG 2016 sepanjang terkait dengan definisi merek suara dan registrabilitas merek suara atau Menteri Hukum dan HAM RI membuat peraturan khusus tentang pendaftaran merek suara.

Dalam konteks pembuatan norma baru atas registrabilitas merek suara di atas disarankan agar Menteri Hukum dan HAM mempertimbangkan rumusan atau definisi merek suara sebagai sebuah tanda suara yang ditampilkan secara grafis berupa suara alam maupun suara non-alam atau buatan manusia baik berupa kata-kata atau kombinasi suara atau bebunyian lainnya yang dipakai dalam kegiatan produksi barang dan jasa dengan tujuan membedakan barang dan jasa sejenis yang diproduksi oleh orang atau badan hukum lainya.

Sedangkan terkait dengan registabilitas merek suara disarankan agar Menteri Hukum dan HAM mempertimbangkan membuat peraturan pelaksanaan pendaftaran merek suara dimana registrabilitas merek suara diatur secara lebih tegas dan jelas dengan disertai contoh pembuatan notasi, rekaman suara dan sonogram. Registrabilitas merek suara di Indonesi sebaiknya meliputi penegasan bahwa a) tanda suara tersebut harus dipakai dalam kegiatan perdagangan barang dan jasa; b) 
tanda suara tersebut harus membedakan barang dan jasa sejenis yang diproduksi oleh orang atau badan hukum lainnya; c) label merek suara harus ditampilkan secara grafis berupa notasi, rekaman suara dan/atau sonogram; d) dalam hal tampilan grafis berupa notasi, maka jumlah notasi maksimal adalah 12 ; e) dalam hal tampilan grafis berupa rekaman suara maka durasi maksimalnya adalah 12 detik; f) dalam hal tampilan grafis berupa notasi, maka perlu disertai dengan keterangan kata-kata yang diletakan di bawah notasi yang disertakan dalam permohonan; g) dalam hal tampilan grafis berupa sonogram maka perlu disertakan notasinya dengan jumlah maksimal adalah 12 dan durasi maksimal 12 detik. Diharapkan pengaturan yang jelas mengenai definisi merek suara dan registrabilitas merek suara yang lebih jelas dan limitatif bisa memberikan jaminan kepastian hukum bagi pemohon pendafaran merek suara di Indonesia.

\section{DAFTAR PUSTAKA}

Bretonniere, J. F., \& Rodari, S. (2009). Global-Protecting and enforcing nontraditional trademarks. Building and enforcing intellectual property value. IP Value.

Calboli, I. (2018). Chocolate, Fashion, Toys and Cabs: The Misunderstood Distinctiveness of Non-Traditional Trademarks. IIC - International Review of Intellectual Property and Competition Law, 49, 1-4.

Calboli, I., \& Senftleben, M. R. F. (2018). The Protection of non-traditional trademarks: critical perspectives (First Edit). Oxford, United Kingdom: Oxford University Press.

Carapeto, R. (2016). A Reflection About the Introduction of Non-Traditional Trademarks. Waseda Bulletin of Comparative Law, 34, 25-60.

Clarke, B., \& Kapnoullas, S. (2001). The New Forms of Registrable Marks:
Market Uptake in the First Five Years. Deakin Law Review, 6(1), 70-90.

Court of Justice EU. (2003). Court of Justice EU 27 November 2003, Judgment Of The Court (Sixth Chamber) 27 November 2003. Retrieved from https://www.ippt.eu/sites/default/files/2 003/IPPT20031127_ECJ_Shield_Mark _-_soundmark.pdf

Direktorat Jenderal Kekayaan Intelektual. (2006). Nomor Pendaftaran D002006027137. Retrieved from https://pdki-

indonesia.dgip.go.id/detail/D002006027 137? type $=$ trademark $\&$ keyword $=\mathrm{D} 0020$ 06027137

Direktorat Jenderal Kekayaan Intelektual. (2017). Nomor Pendaftaran D002017018614. Retrieved from https://pdki-

indonesia.dgip.go.id/detail/D002017018 614?type $=$ trademark \&keyword $=$ D0020 17018614

Direktorat Jenderal Kekayaan Intelektual. (2020a). Nomor Pendaftaran IDM000714016. Retrieved from https://pdkiindonesia.dgip.go.id/detail/D002017044 125? type $=$ trademark \&keyword=IDM00 0714016

Direktorat Jenderal Kekayaan Intelektual. (2020b). Nomor Pendaftaran IDM00075474. Retrieved from https://pdkiindonesia.dgip.go.id/search?type $=$ trade mark\&keyword=IDM00075474\&id=D0 02017044125

European Union. (2015). Directive (EU) 2015/2436 of the European Parliament and of the Council of 16 December 2015 to approximate the laws of the Member States relating to trade marks.

Gheewala, S. (2007). Singapore Sling: WIPO Passes the Buck on Meaningful Reform of International Trademark Law. The DePaul Journal of Art, 
Technology \& Intellectual Property Law, 17(2), 305-337.

Kudrina, Y. (2018). Non-Traditional Trade Marks And The Abolition Of The Requirement For Graphical Representation - EU Trade Mark Registration Process. Stockholm University. Retrieved from http://www.divaportal.se/smash/get/diva2:1195299/FUL LTEXT01.pdf

Lukose, L. P. (2015). Non-Traditional Trademarks: A Critique. Journal of the Indian Law Institute, 57(2), 197-215.

Rissy, Y. Y. W. (2020). Memahami Rezim Kekayaan Intelektual Internasional dan Indonesia. Salatiga: Griya Media.

Sandri, S., \& Rizzo, S. (2003). Nonconventional trade marks and Community law. Thurmaston, Leicester: MARQUES, the Association of European Trade Mark Owners.

Scardamaglia, A., \& Adams, M. (2016). Registering Non-Traditional Signs as Trade Marks in Australia: A Retrospective. Australian Intellectual Property Journal, 26(3), 149-163.

Seville, C. (2009). EU Intellectual Property Law and Policy. United Kingdom: Edward Elgar Publishing.
Vaver, D. (2005). Unconventional And Well-Known Trade Marks. Singapore Journal of Legal Studies, 1-19.

World Intellectual Property Organization (WIPO). (2008). Standing Committee on the law of trademarks, industrial designs and geographical indications (Nineteenth Session): Representation and Description of Non-Traditional Marks Possible Areas of Convergence. Retrieved from http://www.wipo.int/edocs/mdocs/sct/en /sct_19/sct_19_2.pdf

World Intellectual Property Organization (WIPO). (2009). Smell, Sound and Taste - Getting a Sense of NonTraditional Marks. World Intellectual Property Organization (WIPO) Magazine. Retrieved from https://www.wipo.int/wipo_magazine/e $\mathrm{n} / 2009 / 01 /$ article_0003.html

World Intellectual Property Organization (WIPO). (2018). Guide to the International Registration of Marks under the Madrid Agreement and the Madrid Protocol. Geneva: World Intellectual Property Organization. Retrieved from https://www.wipo.int/edocs/pubdocs/en/ wipo_pub_455_2018.pdf 